\title{
Liberal education in turbulent times: Policy, pedagogy and their effects in European comparison
}

Peter Kelly iD

\section{How to cite this article}

Kelly, P. (2020) 'Liberal education in turbulent times: Policy, pedagogy and their effects in European comparison'. London Review of Education, 18 (1): 35-49. https://doi.org/10.18546/LRE.18.1.03

Submission date: 15 May 2019

Acceptance date: 12 November 2019

Publication date: 1 March 2020

\section{Peer review}

This article has been peer reviewed through the journal's standard double-blind peer review, where both the reviewers and authors are anonymized during review.

\section{Copyright}

(C) Copyright 2020 Kelly. This is an Open Access article distributed under the terms of the Creative Commons Attribution Licence (CC BY) 4.0 https://creativecommons.org/licenses/by/4.0/, which permits unrestricted use, distribution and reproduction in any medium, provided the original author and source are credited.

\section{Open access}

Research for All is a peer-reviewed open-access journal. 


\title{
Liberal education in turbulent times: Policy, pedagogy and their effects in European comparison
}

Peter Kelly* - University of Plymouth, UK

\begin{abstract}
Europe has seen a national populist turn in recent years, a movement away from liberal elites and the rise of 'post-truth' politics. While populist parties may have passed the high point of their success, their politics has had a considerable impact on the mainstream, drawing traditional parties in populist directions. In this article, I consider the consequences of this for those of a liberal persuasion, who value openness and diversity and who are suspicious of those bringing simple solutions to complex problems. I reflect on the findings of a series of comparative education policy and pedagogy studies that I have conducted with colleagues in northern Europe over the past ten years, and in their light, make a number of suggestions for how education can defend liberalism while taking the concerns of national populists seriously.
\end{abstract}

Keywords: neo-liberal education reform, populism and education, sceptical liberalism, democratic governance, educational purpose, methodological pluralism

\section{A call for change}

Neo-liberal ideas have shaped social reform agendas to varying degrees in many European countries since the 1980s. More recently, this has been accompanied by a growing mistrust in the liberal establishment, exacerbated by the financial crisis of 2007. In this context, national populists have gained influence by challenging the status quo and calling for policies that, in their view, better serve the interests of ordinary people (Eatwell and Goodwin, 2018). While populist parties may have passed the high point of their success, they have drawn traditional parties in populist directions. The purpose of this article is to consider the consequences of rising popular discontent for those of a liberal persuasion; how should those who value openness and diversity, and who are suspicious of those bringing simple solutions to complex problems, respond? Clearly, liberalism must learn lessons, and education, which is at the centre of liberal social policy, must play its part; despite the good intentions and hard work of committed educationalists, many students remain marginalized and alienated by the policies of the neo-liberal extreme. Using Bourdieu's (2014) theory of the state and Fuller's (2018) analysis of post-truth, I reflect on the findings of a series of comparative education policy and pedagogy studies that I have conducted with colleagues in northern Europe over the past ten years (Andreasen et al., 2015; Kelly, 2018; Kelly and Kotthoff, 2016, 2017; Kelly, Hohmann et al., 2013; Kelly, Pratt et al., 2013; Kelly et al., 2014, 2018). In light of this, I suggest a credo for how education can defend liberalism while taking the concerns of national populists seriously. 
The term neo-liberal refers here to those seeking to maximize human flourishing through market processes (Harvey, 2007). This has become a policy technology of nation states seeking to improve welfare provision, and marketization in education, mobilized by comparative student evaluation through high-stakes testing, dominates national education reform agendas $(\mathrm{Au}, 2008)$. In this context, international comparative student tests, such as the Organisation for Economic Co-operation and Development's (OECD) Programme for International Student Assessment (PISA) surveys, have played a significant role in encouraging neo-liberal education reform programmes (Mundy et al., 2016).

\section{Neo-liberal ascendancy, populist backlash}

Green (2013) has shown how education is central to the formation and consolidation of modern statehood and national identity. For the liberal state, schools, in particular, develop citizens and workers capable of pursuing their own goals and furthering the common good. But rising international and European governance and transnational activities have lessened state sovereignty. Nordin and Sundberg (2014) show how international organizations such as the OECD, which administers and analyses the PISA comparative tests, and the European Union (EU), whose education mission has become supporting the cross-national growth of human capital, are now highly influential. It is widely recognized that PISA comparisons alone have had a major impact on countries such as Denmark and Germany, where the national shock of a mediocre PISA 2000 performance (OECD, 2001) gave impetus to significant programmes of education reform (Ertl, 2006; Hermann, 2007; Waldow, 2009). Yet in recent years, the role of the OECD has increased as it has provided explanations for national differences in PISA scores and made policy recommendations (Sellar and Lingard, 2014). Alexiadou's (2014) analysis of the EU's Open Method of Coordination shows how the European Commission's (EC) governance activities stretch into education, for which the EU has no legislative remit, by providing a European architecture for cross-national policy learning. This includes EC-funded networks such as the European Policy Network on School Leadership, which ran from 2011 until 2014 with the aim of disseminating best practice and evidence of what works through teacher organizations in member states.

In seeking to harness market mechanisms to maximize school success (Harvey, 2007), the tone of international and European governance has been largely neo-liberal (El Bouhali, 2015). Both the OECD and the EU use PISA data to compare national education systems, and both provide information and guidance to challenge those less successful to improve. This has increased pressure on policymakers for neo-liberal reform, leading Lingard et al. (2013) to add a level of global governance to Ball and Bowe's (1992) policy cycle. National administrations have become preoccupied with governance by numbers (Ball, 2015; Ozga, 2008), as international comparative survey data complement domestic testing regimes as commensurate spaces for measurement (Lingard, 2011). As a result, national education reform agendas often share performative similarities (Ball, 2013); test-based accountability regimes increasingly regulate the work of schools, school managers and teachers within the context of greater school autonomy (Stevenson and Wood, 2013).

This sits within the wider social phenomenon of late modernity (Bauman, 2000; Giddens, 1990). No longer subjects or nationals, strongly allied to countries that clearly demarcate the limits of government, people have become collections of individuals, attached to diverse and multiple affiliations in social spaces fluid with migration and, 
because of technology, unrestrained by the limitations of nation states. Accompanied by economic instability, precarious employment and a mistrust of those in public service, particularly politicians, these changes can be characterized as reflecting a crisis in authority, tradition and scientific certainty (Gray, 1995).

National populists (Eatwell and Goodwin, 2018) identify neo-liberal globalization as the primary cause of this crisis, widening inequality and increasing alienation. Claiming a betrayal of ordinary people by the neo-liberal state, they demand: (1) democratic reform, so that the popular will is heard and acted upon; (2) a respect for ordinary people, who are often identified with a heartland, a culture that is viewed as being authentic, hard-working and endowed with common sense; and (3) the replacement of the elites, whom they blame for their situation, while also targeting others such as immigrants. The term post-truth emerged from the election of Donald Trump in the USA and the UK's Brexit decision in 2016, as a reaction to national populist critiques of the political and economic establishment as self-serving. It referred specifically to populist denials of authority or expertise, which they believed were being conscripted by the political elite to defend their claims. Post-truth was used in a derogatory way to portray populists as giving their subjective opinions the same status as objective facts while ignoring debate about the nature of those opinions or facts (Davis, 2017). Yet some regard this definition itself as a post-truth attempt to take the moral high ground, rather than viewing all knowledge claims to be a combination of evidence and opinion (Fuller, 2018).

\section{The populist threat and Berlin's case for sceptical liberalism}

Populists draw on idealized and protectionist versions of national sovereignty and essentialist views of culture and, in valorizing the notion of a popular will, seek majoritarian approaches to political decision-making. For liberals who value diversity within an open society, each of these is deeply problematic. Isaiah Berlin's (1969) value pluralism recognizes that the many difficulties faced by decision-makers in complex and constantly changing societies are compounded by the diversity of values and beliefs that shape people's lives, not all of which are commensurate. For Berlin (1969; 2013), liberty has two faces. The first called negative, concerns freedom from constraint, be it the authority of a single viewpoint or individual, or the view of the majority imposed on the minority. He prefers this to the second, the positive freedom to act as a rational, self-governing agent, which he regards as problematic as it implies a monistic view of the human good:

True pluralism, as Berlin understands it ... rejects the view that all conflicts of values can be finally resolved by synthesis and that all desirable goals may be reconciled. It recognises that human nature generates values which, though equally sacred, equally ultimate, exclude one another, without there being any possibility of establishing an objective hierarchical relation among them. Moral conduct may therefore involve making agonising choices, without the help of universal criteria, between incompatible but equally desirable values. (Kelly, 1978: xxvi)

Fundamental to Berlin's (2013: 14) position is his scepticism about the attainability of certain knowledge from a single standpoint: 
The notion of the perfect whole, the ultimate solution in which all good things coexist, seems to me not merely unobtainable - that is a truism but conceptually incoherent.

Indeed, for Berlin, the social world cannot be studied using the same model as the natural sciences, and he rejects all forms of methodological monism, advocating instead 'the view that the methods of inquiry appropriate for different subject matters may, and do, vary with differences in these subject matters' (Gray, 1996: 48).

Building on Berlin's arguments for negative freedom, Gray (2002) argues that liberal institutions (whether governmental, those of civil society, including the likes of schools tasked through social policy to moderate inequalities, or commercial) should allow people with incommensurate values to live alongside each other, promoting coexistence by bringing diverse viewpoints together in a spirit of toleration and compromise. This is not to contradict Berlin, who rejected coexistence as an end, an achievable solution. Rather, Gray acknowledges this as an ongoing struggle, a process requiring constant vigilance and active engagement. His political solution valorizes the deliberative over not only the authoritarian and the majoritarian, but also the invisible market hand, driven by rational self-interest.

Taking Berlin's position, we might agree that schools should prepare their students for citizenship and work, but must also accept that there are many ways of understanding the world and our place in it, what it is to be a good citizen or employee, or how to lead a good life, each based in different and sometimes incommensurate values. Instead of valorizing a single perspective, schools should represent a diversity of values and encourage their students to explore their own and others' values and the beliefs in which they are rooted, thereby promoting understanding and tolerance of the diverse values by which people live, and the willingness to compromise needed for them to live alongside each other. Applying this position to diversity in schools themselves, we should recognize that there are many ways of understanding education, providing a good education and being a good teacher or student, depending on the values and beliefs underpinning each. Nevertheless, it is important not to mistake this for moral relativism; political process allows for the mediation between incommensurate values, the prioritization of some values over others and social agreement on what is and is not acceptable or desirable.

\section{Lessons from existing studies}

To govern defined or sovereign territories, Bourdieu (2014) argues that nation states possess a monopoly over both physical - which can include mental or emotional and symbolic violence. States inflict this violence by classifying people, objects and activities using categories that legitimate the privilege of the dominant. The doxic state regards the social world as operating according to common sense, where circumstances and objectifications, including state-sponsored category systems, are taken for granted and considered the natural state of affairs. Those resisting categorization and its consequences are subject to mental or physical coercion to ensure they comply. But others misrecognize their categorization by the state and its consequences, regarding these as right and just, a measure of their own natural worth, and so are subject to symbolic violence. Education is an important part of the state apparatus for categorizing people, objects and activities thus.

In a series of comparative studies with colleagues in Denmark, England and Germany over the past ten or so years (Andreasen et al., 2015; Kelly, 2018; Kelly and Kotthoff, 2016, 2017; Kelly, Hohmann et al., 2013; Kelly, Pratt et al., 2013; Kelly et al., 
2014 , 2018), I have sought to map the extent and progression of neo-liberal education reform in three north European national contexts, analysing how this has shaped pedagogy and its impact on teachers and students. These studies have explored how marketization, managerialism and performativity in education, mobilized by high-stake student testing and test-based accountability regimes, widen educational inequality and increase teacher and student alienation. In so doing, this research has explored the processes through which states inflict violence on those they purport to serve, as a consequence of classifying activities. This work has been important in showing how policy and strategy originating at the supranational or national level affects people on the ground. Berlin (1978) suggests that, in War and Peace (1869), Tolstoy shows that one cannot understand the winning of battles by examining political leadership and military strategy alone; it is on events and the complexity and messiness of the fray that things turn. Similarly, you cannot understand the role of education in exacerbating the liberal crisis and fuelling the rise of populism solely through macro-sociological analyses. It is individuals, complex and diverse, yet often sharing a sense of who they are with those whose experiences are similar, who are alienated by schooling and feel vulnerable and marginalized in their communities; feelings implicated in the rejection of liberalism and coexistence, the populist turn and protectionists' demands against those deemed to be other (Eatwell and Goodwin, 2018).

\section{Educational purpose and pedagogy}

Taking Bernstein's $(1990 ; 1996)$ pedagogic device as our starting point, three articles (Kelly, Hohmann et al., 2013; Kelly, Pratt et al., 2013; Kelly et al., 2014) develop an account of the formation of situated pedagogy, emergent from negotiations between classroom participants, and thus contingent on and reflecting the dominant values of the circumstances in which it takes place. In so doing, this work challenges idealized, singular and universalist views of pedagogy that assume it is in the gift of teachers to determine the act of teaching. To some extent, this account develops Ball and his colleagues' (2012) analysis of policy enactment, by providing a framework for comparing pedagogies situated in different cultural contexts. The study on which these articles report compared national language and mathematics teaching in lower secondary comprehensive schools in Denmark and England, mapping the effect of pedagogy on students' engagement with each subject. In retrospect, it is evident that three features of teaching were already established within the English teaching context from 2007 to 2012 when the study took place: a focus on skills coaching, on teaching as a performance and on top-down approaches to classroom management. Such approaches were privileged by the categorization and classification processes of high stakes student testing and test-based accountability for schools and teachers, and contrasted with the subject expertise and supervisory roles that dominated in Danish classrooms, where teachers were also less controlling.

For Biesta (2010a), educational purpose concerns qualification, socialization and subjectification. The first, qualification, involves the development and appraisal of curricular understanding. Socializing students into different cultures or ways of being is a second key educational goal. While education might anticipate workplace or citizenship cultures, for the most part, it socializes students into classrooms. The socialization of students, combined with their curricular experiences, shapes them as individuals, or subjects, as Biesta calls them. This is Biesta's third educational goal: ideally, for him, enabling students to become autonomous and independent thinkers, to acquire positive freedom, despite Berlin's protestations at the difficulties of this. Our research shows how neo-liberal education reform distorts the work of schools 
solely towards qualification, at the expense of the other two; unintentionally, children are socialized into classrooms focused on test preparation, and their subjectivities reflect this, as I discuss later. The more balanced approach of teachers in Denmark deliberately sought to socialize students into largely inclusive and enquiring classroom communities through a process of Erziehung, supporting the formation of student subjectivities through academic work in a process of Bildung.

The sociocultural lens used in our analysis allowed us to explore how teaching in established and emergent neo-liberal contexts shaped the socialization of students and formation of their subjectivities. Beyond their explicit categorization as high, middle or low achievers, teacher performers positioned learners as a rather passive audience. This was reinforced by authoritarian command and control styles of management, where teachers took responsibility for student learning and students had few opportunities to make choices for themselves about how to organize and proceed with their studies. These resulted directly from test-based accountability, which positioned teachers as responsible for student learning, while the high stakes meant they did all they could to minimize uncertainties around student test performance through controlling pedagogies. But probably of greater significance was how skills coaching invoked what Bernstein (1999) calls a horizontal subject discourse, while in order to develop the subject understanding required for achieving higher examination pass levels, students need to ascend a vertical subject discourse. Horizontal discourses are everyday ways of talking and thinking in the world. They are immediate and embodied, and underpin the activities that we engage in routinely and the knowledge required to be proficient at work. Such discourses are recontextualized into schooling as knowledge application and problem-solving activities. Curriculum reforms in England repackaged subjects such as English and mathematics as skills sets called literacy and numeracy, thereby assuming the usefulness and transfer of the ideas and procedures taught. Whereas horizontal discourses are situated in prevailing common-sense world views, vertical discourses make relational sense of the world in increasingly sophisticated ways; the move from simple calculation to algebraic manipulation in mathematics constitutes one aspect of a vertical mathematics discourse, while that from literal descriptive writing to poetry and metaphor lies within a vertical language discourse.

By regarding teacher and student roles as reciprocal, we explained why the progress of low achievers in neo-liberal contexts is more limited than those in more humanist contexts. In England, by putting test success down to a combination of talent and hard work, a common-sense position, the neo-liberal state legitimized the privilege of higher achievers. Meanwhile, controlling and sometimes coercive pedagogies based on rote, repetition and drill were used to discipline low achievers and ensure their hard work. While such pedagogies had little effect, in an act of symbolic violence they reinforced the view that the failure of lower achievers was deserved. It is not that Danish pedagogies were unproblematic. Mixed ability teaching ensured low achievers had access to both a vertical and horizontal discourse in Danish and mathematics lessons, but teaching was strongly regulated by the nature of these subjects themselves, while teacher roles were strongly paternalistic; teachers saw themselves as responsible for students, not their learning, and ensured that students did the right thing and developed into socially active and responsible workers and citizens. The professional autonomy of teachers in Denmark allowed them considerable discretion in deciding what this meant, imposing their own value systems on those they taught. 


\section{Educational governance and pedagogy}

Two further articles report the findings of a second study that took place from 2012 to 2014, comparing pedagogy formation in comprehensive and selective schools in England and Germany (Kelly and Kotthoff, 2016, 2017). To ensure a more systematic comparison, we first analysed the extent of neo-liberal education reform in each context, which ranged from established in England to emergent in Germany, and within this looked at the balance of hard and soft governance approaches used by administrators to mobilize reform and shape teaching.

Ball's (2013) account of policy technologies was used to analyse the degree of marketization, managerialism and performativity in each context, and determine the extent of neo-liberal education reform. Not only has the quasi-market in England institutionalized competition between schools and teachers through comparative student tests, but it has also opened schools up to commercial interests in areas such as student data analysis, professional guidance and curriculum, teaching and assessment materials, thereby allowing for the incremental privatization of pedagogy. Within this context, command and control decision-making has been centralized in an ascendant class of school managers, the clergy for the state's categorization activities, valuing improved test performance alone and measuring the worth of people and pedagogy against this.

Without public information on student assessments, marketization in Germany is more limited, although parents are increasingly able to choose schools for their children. Nevertheless, the same single hard governance pressure towards securing improved exam results operates in both contexts as the primary vehicle for neo-liberal education reform; while the focus in England remains national GCSE examinations, in Germany the supranational influence of PISA tests dominates. PISA has historical significance in Germany, following the 'shock' of the 2000 results. This has led, in Germany, to a central role for textbooks in the soft governance of pedagogy in lower secondary mathematics lessons in comprehensive schools, through their focus on PISA-like problems, while mathematics teaching of students of the same age and in similar schools in England is more obviously test-focused.

Textbooks in Germany for middle- and low-achieving students follow guided exercises on the rules of mathematics, with opportunities to make use of these rules to solve routine everyday problems. This allows for some vertical development, as new rules build on old ones in an increasingly sophisticated manner. In comprehensive schools in England, low-achieving students in particular are grouped for instruction, and their follow-up work is often highly individuated, affording few opportunities for peer support. Teaching often focuses on routine calculation, using various models and techniques to help students remember what to do. However, these approaches seldom encourage students to think more mathematically about tasks, thus limiting their access to a vertical discourse. Yet what is remarkable is how little education reform agendas have affected elite institutions in each country. In particular, both grammar schools in England and Gymnasia in Germany continue to focus on mathematics as a subject with clear boundaries and a strong tradition, and encourage student responsibility for their own learning, clearly engaging students in a vertical mathematics discourse.

Building on earlier work with colleagues, this study identified the important role knowledge plays in misrecognizing the academic success of some and failure of others as right and just, a measure of each group's natural worth. While the categorization of students for school selection leads to very different student experiences by design in both countries, students in comprehensive schools in England appear to follow the 
same broad and balanced curriculum irrespective of their assessment categorization, although setting arrangements and the use of tasks matched to perceived need leads to differences in student experience. Homes rich in economic, cultural and social capital bestow significant advantage on children in their schooling, and the capacity to engage in a vertical discourse is strongly associated with a more privileged upbringing. Vertical subject discourses are key to academic success. But rather than facilitating the engagement of less socio-economically advantaged students with vertical subject discourses, a long-term activity and approach that dominates selective education and comprehensive education including that of low achievers in Germany, neo-liberal pressures ensure English comprehensive schools focus on short-term measures set within horizontal subject discourses to boost test scores. Hence, no matter how hard students work, many will never do as well as their more privileged peers; yet their often, at best, mediocre performances are regarded as reflecting a lack of application and hard work.

\section{The long shadow of high-stakes assessment}

The most recent study, which concluded in 2017, focused on comparing the governance effects of reading tests on teaching and students aged 11 in primary schools in England, and folkeskoler, which combine primary and secondary education between the ages of 7 and 16 in Denmark (Andreasen et al., 2015; Kelly, 2018; Kelly et al., 2018). Although student assessments in Denmark were intended to be formative, and took the form of adaptive computer-based tests, while those in England were formal pencil and paper tests intended as primarily summative, each had a shaping effect on teachers and students that varied only in degree, depending on the stake attached to test outcomes. As the stakes become higher, their impact on teaching greatly increases.

This study confirmed how high-stake tests narrow the curriculum in favour of those subjects tested, increase the amount of teaching to the test, promote shallow learning and short-term knowledge retention, and increase student stress and demotivation (House of Commons Children, Schools and Families Committee, 2008). We also saw increased teacher-centred instruction, the focusing of resources on groups of students identified at grade borderlines to maximize league table impact, and an increase in schools choosing and excluding students to raise scores (Stevenson and Wood, 2013). In addition, we sought to chart the changing landscape of neo-liberal governance to show how, as neo-liberal education agendas become more established and testing more influential, opportunities for teachers to draw on their professional knowledge of teaching, learning and students are constrained by their need to prioritize immediate demands. We considered teachers in neo-liberal contexts to be no less caring or conscientious than those elsewhere, but their wish to be proactive is compromised by their need to be responsive, as they become less reliant on professional judgement and more on external measures and systems of categorization. The tension and confusion between two distinct forms of pedagogy - crudely put, the deliberate and the responsive - and a wish for a return to the former causes educators considerable angst. It is in this context that managerialism, which constantly mistakes control over work for control over learning, comes to dominate both school organization and classroom practice, because this serves the interests of school leaders and teachers in high-stakes contexts better than more laissez-faire approaches by providing a degree of predictability and certainty to the relationship between classroom activity and test outcomes. However, the relatively high professional autonomy of Danish teachers posed other problems not seen in the English context, particularly with regard to the largely negative value judgements they made about students from working-class and 
migrant backgrounds; a paternal, common-sense chauvinism reflecting taken-forgranted assumptions that underperforming groups are largely responsible for this themselves, and that the role of schools is to bring them into the middle classes.

Our analysis identified two dominant processes in neo-liberal contexts. First, using student test outcomes to hold teachers and schools to account brings a fragmentation of interests, as individuals compete to ensure that national testing processes and outcomes work in their interests. Second, everything is treated as means to test success in a process that privileges utility above engagement, understanding and compassion, resulting in the dehumanization and commodification of knowledge and people as entities exchangeable for market advantage.

The effects of these processes on students are startling; they widen educational inequality and increase alienation, particularly of low achievers. As with earlier studies, this work confirmed the lack of vertical subject discourse in teaching designed to boost test scores, but students' subjectivities were also clearly stratified in their relation to reading. Reading confidently affirms who high achievers are and their place in the world. Theirs is a craft relationship to reading (Sennett, 2009), fully engaged, always aspiring to improve and enjoying much personal satisfaction and the respect of others. Low achievers, however, are alienated from reading, as Marx (1975: 326) eloquently expressed:

he does not affirm himself but denies himself, does not feel content but unhappy, does not develop freely his physical and mental energy but mortifies his body and ruins his mind ... He is at home when he is not working, and when he is working he is not at home. His labour is therefore not voluntary, but coerced; it is forced labour.

This is the outcome of a regime of symbolic violence; yet learners continue to consent to this treatment, with low achievers acknowledging their dependence on teachers to help them, while apologizing for their lack of talent.

\section{Education knowledge traditions}

The doxic state regards the social world as operating according to common sense, where circumstances and objectifications are taken for granted and considered the natural state of affairs. Among other things, it suits the interests of the state to take the nature of knowledge for granted, as an object delivered in lessons, acquired by learners, stored in their heads and recalled in a straightforward manner to answer test questions. This allows administrators to claim that test scores adequately capture students' subject proficiency and, consequently, the quality of teaching they received and schools they attended. This is coupled with the assumptions of meritocracy; while school success is down to a combination of talent and hard work, all can make the most of their capacities and 'be the best they can be' if they are conscientious. Nevertheless, it is argued, a good teacher and school can make a huge difference. In recent years, forms of education knowledge traditions which fit with this common sense have become influential.

In this context, a new science of education has emerged (Whitty and Furlong, 2017), which promises to find out 'what works' through the application of rigorous research methods, typically in the form of randomized controlled trials, systematic reviews and using methods taken from the natural sciences, while eschewing ideological and theory-led approaches. This pragmatic stance fits well with neo-liberal reform and the common-sense logic of the doxic state (Bourdieu, 2014), by seeking 
to identify approaches that raise student achievement most efficiently and effectively within a marketplace of education practices. Bernstein $(1996,1999)$ calls these regional knowledge traditions because of their thematic nature. This evidence-led movement has sought to challenge academic elites and traditional professionalism, replacing the authority of the education disciplines of history, philosophy, psychology and sociology in England or of Bildung, Erziehung, Didaktik and Pädagogik in Germany, referred to as singulars by Bernstein because of their discrete, substantive and clear legitimization discourses, or the practical initial teacher education craft knowledge traditions of both countries. Their project is one of democratizing knowledge; bypassing both the ideological teacher educators and the 'secret garden' of traditional professional knowledge and its priesthood of experts and advisers, and ignoring their elaborate and pompous theories to provide, instead, straightforward evidence of what works in raising student standards to all - school principals, managers and teachers - so that they can act on this evidence to their own and their students' advantage, wherever they live and whatever their background. In aligning with common sense and challenging elites, apparently in defence of ordinary people, this new science constitutes a form of educational populism, albeit different in nature to broader movements, while also supporting misrecognition.

Indeed, this is a problem with populism per se; one common sense, that of modernity, which assumes the inevitability of human progress and the benign authority of technocrats and professionals, is replaced by another that believes in the compassionate good of authentic, hardworking people; but even casual reflection on these would suggest that neither is particularly convincing. So, while ordinary people are subaltern to the experts of the paternal state and those of low socio-economic status to the neo-liberal state, it is groups and individuals considered culturally 'other' who will lose out in a populist state.

\section{Trust and reform}

The growth of national populism represents a breakdown in trust between ordinary people and the political and economic establishment. Traditionally, trust involved 'the vesting of confidence in persons or in abstract systems, made on the basis of a "leap of faith" which brackets ignorance or lack of information' (Giddens, 1991: 244). But under neo-liberal reform, authority, ideology and tradition, regarded as inflexible, unresponsive and steeped in vested interests, are replaced by faith in an 'invisible hand'. This changed emphasis is seen in moves from the government of institutions through edict and directive to their governance through market mechanisms, as I have already discussed, which has led to a fragmentation of interest within increasingly entrepreneurial state institutions, as employees no longer serve the public good alone, but are torn between multiple public and private goods. Ironically, the privatization of state institutions, which was intended to make them more efficient and effective in their role of moderating various social inequalities and promoting social mobility, has instead led them to replicate or even exacerbate these inequalities.

To allow competition between and choice of schools, education consumers require information to compare education providers. Such comparisons are complex, not least because, as competitors, schools often seek to present themselves in the best light. So, institutions aligned with methods adapted from science that emphasize impartiality and detachment are tasked with simplifying this complexity for public consumption. In England, Ofsted evaluations, which serve to hold schools and teachers to account, are based on clear criteria linked to common standards. Interestingly, 
the test of this clarity is reliability of judgement - any two inspectors considering the same evidence should award the same grade. But reliability comes at a cost; the basis on which judgements are made must be straightforward and uncontentious, yet, as I have explored, schools and classrooms are riven with the contingent intricacies of social practice. The solution has been to move from evaluating process to evaluating outcome, where it is believed the data can 'speak for itself'. Hence, the most influential evidence source is student performance data, measured using standardized in-school tests or end-of-school examinations.

For Bourdieu (2014), agents of the state, be they institutions or individuals, are trusted when the underlying interests of the powerful whom they represent are misrecognized as voluntary, disinterested action and exchange. Buying into the truths we are told about schools and by schools means accepting the common-sense logic underpinning them, as I discussed earlier. But this does not always happen. Against the backdrop of an education landscape where 'outstanding' Ofsted gradings are the norm, year-on-year improvements in student test scores have long been the subject of media scepticism, while students recognize that their qualifications do not open the doors they are meant to. Teachers know that students boosted to achieve at one level continue to underperform at the next. Meanwhile, student exclusion and teacher attrition rates remain high, and a cause for public concern. The everyday alienation of students identified in the studies revisited in this article, and of teachers subject to testbased accountability and associated managerialism can also be added to this picture. Each involves emotional and symbolic violence, and each provides an opportunity to see past explanations based on notions of personal failing, to focus instead on the unjust actions of the neo-liberal state. Those who no longer trust the state to act in their best interests may be inclined to resist, potentially provoking coercive action: students through disciplinary codes, ultimately leading to their removal from schools, parents through prosecution if, in England for example, they allow their children to miss school, and families through the interventions of social workers.

Demands for educational reform are mostly common-sense responses to obvious concerns, such as the fairness of examinations and their distortion of teaching. There are also regular exhortations to make curriculum and pedagogy more relevant, further exploit the benefits of technology, and increase the scope and status of vocational education, among other things. Each is a call for schools to address with students the concerns of today and better prepare them for the world of tomorrow. But the role of vertical discourse remains consistently invisible in both analyses and solutions. Hence, while the resulting initiatives may increase trust and reduce the alienation of some, it is unlikely they will significantly reduce educational inequality. They represent a progressive conservatism; progressive in appearance, but conservative in nature.

It is true that some, such as Hirsch (1987) and Young (2008), who inspired Michael Gove's reforms as Secretary of State for Education in England and Wales, for the Coalition Government from 2010 to 2014, have argued for a return to a knowledgecentred curriculum in schools. Their call, however, is set within the same common-sense view of knowledge already discussed, while the curricular knowledge they valorize is singular or monist, taken from what we might call the Western canon of, as Arnold says in the Preface to Literature and Dogma (1873), 'the best that has been known and said in the world, and thus with the history of the human spirit'. So, like the progressive conservatives, this more regressive conservatism is also advocated without attending to the difficulties that low socio-economic status students face when presented with vertical subject discourses. 
Earlier, I noted Fuller's (2018) argument that the term post-truth represents all knowledge claims as a combination of evidence and opinion; what counts as truth is socially contingent, which also fits with Berlin's view outlined earlier. Fuller (2018) reminds of the distinction made by Durkheim between outward appearance (the profane) and a more sophisticated but sometimes hidden reality (the sacred), which parallel Bernstein's (1999) horizontal and vertical discourses, and suggests that common-sense appearance often ends up passing for complex reality. As has been noted already, common-sense appearance often masks the workings of power in the maintenance and reproduction of social inequalities, which relational analyses, such as that of Bourdieu (2014) presented here, expose. Only methodological pluralism (Gray, 1996) in social research has a chance of casting light on complex reality.

The populist critique is a common-sense critique, but the late modern condition is an epistemological crisis of authority, tradition and scientific certainty (Gray, 1995). We can re-establish trust in a revised common-sense settlement, or we can help people to live with uncertainty and embrace value pluralism. My own view is that reducing academic inequalities can help here, not only as a step towards a more equal society; vertical subject discourses allow students to apprehend the sacred, in Durkheim's terms, challenging common sense to explore the hidden complexities behind unpredictable and, for some, unnerving social events. There is comfort too in knowing how others have made sense of their lives and the world in which we live.

\section{Responding to the populist critique}

If we accept the populists' analysis of late modernity while rejecting their platform, there are a number of issues they raise, which are reflected in the studies reviewed here, which must be taken seriously by those seeking to defend liberal education. While trust in teachers in England remains quite high, it cannot be taken for granted. As I have discussed, neo-liberal education reform provides both incentives and opportunities for schools, leaders, managers, teachers and others representing multiple corporate and individual interests, to appear self-serving and marginalize the public interest, however defined. This is particularly clear in the tension between testing and inclusion, which provides a dilemma between, on the one hand, ideals about accountability, assessment and measurable levels of success, and on the other, ambitions to create a school system that can support possibilities of participation and learning for all children. However, there are other concerns, particularly with multi-academy trusts (MATs), where there have been many charges of nepotism and excessive remuneration directed at senior managers. There is no reason why government reform agendas seeking to better regulate the tenure and work of schools could not address such concerns.

In response, schools should try to be less paternal or authoritative, and more collaborative and responsive in relations with their communities; situate curricula in local rather than universal needs alone; and allow opportunities for teachers to defend their work with those they serve, thereby increasing local trust, rather than depending on distant experts such as Ofsted to do this for them; all in an ethic of respect for all. For Onora O'Neill, talking in the BBC Reith Lectures in 2002, confidence that institutions are serving the public good lies in increased transparency, open communication and partnership between them and their clients. But in light of Berlin's (1969) position, there must be no compromise with those promoting socially conservative cultural norms and singular views of how to lead a good life, often born of the defensive responses to social cultural change described earlier. 
Were approaches such as these to be pursued, together they might begin to reduce educational inequality and alienation, but without also attending, specifically, to issues of knowledge development, their effects will be partial and time limited.

\section{A liberal education credo}

How can education defend liberalism, while taking the concerns of national populists seriously? In summary, agreeing with Biesta (2010a), the three purposes of educational institutions - qualification, socialization and subjectification - should be kept in balance and not be distorted solely towards qualification. And recognizing the fragmentation of interest that neo-liberal education reform has brought, we must balance a focus on the individual good with unity over a common enterprise and shared ideas of the common good. For example, schools' efforts to raise education standards should not be given precedent over their need to serve all from their communities by creating inclusive environments that celebrate diversity.

While neo-liberal education policy has stressed the need for schools to be datarich and evidence-led, affording managerialism and technocracy, following Fuller's (2018) analysis of common-sense appearance and complex reality, and Berlin's call for methodological pluralism, it should be recognized that, while education theory without evidence can be no better than speculation, evidence developed without theory, such as through 'what works' approaches like randomized controlled trials, by sharing common-sense views, provide an overly simplistic way of understanding the complexities of social practice and how it shapes those participating in it. In this, I agree with Biesta's $(2007,2010 b)$ account of why 'what works' approaches do not work, and with his call for a more nuanced understanding of the relationship between research, policy and practice; one which puts democracy at its fore.

This article has, to a large extent, provided an outline of the limitations of neo-liberal governance. Keeping these limitations in mind, we need to find ways of incorporating expertise, persuasive ideas set in clear value positions, rigorous research and evidence, and an understanding of areas of debate and consensus, into processes of education governance that are subject to adequate scrutiny. Open engagement and discussion in local communities with a diversity of stakeholders should be used to try to ensure these processes focus on shared views of the common good.

Understanding the nature of knowledge is key to understanding educational inequality. Studies mapping the effects of neo-liberal education reform discussed here show how subject understanding loses out to knowledge utility as the domination of testing increases. There are many things we can do to support learners whose socioeconomic status is low, and reduce their discomfort with, and alienation from, learning, without tackling the issue of how to help them develop their subject understanding, and thereby denying them the benefits of doing so. By looking to more humanist education traditions, such as those in Denmark and Germany, we can find some ways to better develop subject understanding. But these traditions often present subjects as singular and authoritative. The challenge is to fully engage students, irrespective of their background, with a plurality of human knowledge; contested and changing, but insightful nevertheless. And we must face this challenge knowing there can be no single, unique way of understanding or addressing it for every child, school or community, and that solutions will be partial, temporary and involve compromise. 


\section{Notes on the contributor}

Peter Kelly is Reader in Comparative Education at the University of Plymouth, UK, where he has worked since 2003. His work compares pedagogy and its effect on educational inequality across northern European countries.

\section{References}

Alexiadou, N. (2014) 'Policy learning and Europeanisation in education: The governance of a field and the transfer of knowledge'. In Nordin, A. and Sundberg, D. (eds) Transnational Policy Flows in European Education: The making and governing of knowledge in the educational policy field. Oxford: Symposium Books, 123-40.

Andreasen, K., Kelly, P., Kousholt, K., McNess, E. and Ydesen, C. (2015) 'Standardised testing in compulsory schooling in England and Denmark: A comparative study and analysis'. Bildung und Erziehung, 68 (3), 329-48.

Au, W.W. (2008) 'Devising inequality: A Bernsteinian analysis of high-stakes testing and social reproduction in education'. British Journal of Sociology of Education, 29 (6), 639-51.

Ball, S.J. (2013) The Education Debate. 2nd ed. Bristol: Policy Press.

Ball, S.J. (2015) 'Education, governance and the tyranny of numbers'. Journal of Education Policy, 30 (3), 299-301.

Ball, S.J. and Bowe, R. (1992) 'Subject departments and the "implementation" of national curriculum policy: An overview of the issues'. Journal of Curriculum Studies, 24 (2), 97-115.

Ball, S.J., Maguire, M. and Braun, A. (2012) How Schools Do Policy: Policy enactments in secondary schools. London: Routledge.

Bauman, Z. (2000) Liquid Modernity. Cambridge: Polity Press.

Berlin, I. (1969) 'Two concepts of liberty'. In Berlin, I. Four Essays on Liberty. London: Oxford University Press, 118-72.

Berlin, I. (1978) Russian Thinkers. London: Penguin.

Berlin, I. (2013) 'The pursuit of the ideal'. In Berlin, I. The Crooked Timber of Humanity: Chapters in the history of ideas. Ed. Hardy, H. 2nd ed. Princeton: Princeton University Press, 1-20.

Bernstein, B. (1990) Class, Codes and Control: Volume IV: The structuring of pedagogic discourse. London: Routledge.

Bernstein, B. (1996) Pedagogy, Symbolic Control and Identity: Theory, research, critique. London: Taylor and Francis.

Bernstein, B. (1999) 'Vertical and horizontal discourse: An essay'. British Journal of Sociology of Education, 20 (2), 157-73.

Biesta, G.J.J. (2007) 'Why "what works" won't work: Evidence-based practice and the democratic deficit in educational research'. Educational Theory, 57 (1), 1-22.

Biesta, G.J.J. (2010a) 'What is education for?'. In Biesta, G.J.J. Good Education in an Age of Measurement: Ethics, politics, democracy. Boulder, CO: Paradigm Publishers, 10-27.

Biesta, G.J.J. (2010b) 'Why "what works" still won't work: From evidence-based education to valuebased education'. Studies in Philosophy and Education, 29 (5), 491-503.

Bourdieu, P. (2014) On the State: Lectures at the Collège de France, 1989-1992. Ed. Champagne, P., Lenoir, R., Poupeau, F. and Rivière, M.-C. Trans. Fernbach, D. Cambridge: Polity Press.

Davis, E. (2017) Post-Truth: Why we have reached peak bullshit and what we can do about it. London: Little, Brown.

Eatwell, R. and Goodwin, M. (2018) National Populism: The revolt against liberal democracy. London: Pelican.

El Bouhali, C. (2015) 'The OECD neoliberal governance: Policies of international testing and their impact on global education systems'. In Abdi, A.A., Shultz, L. and Pillay, T. (eds) Decolonizing Global Citizenship Education. Rotterdam: Sense Publishers, 119-29.

Ertl, H. (2006) 'Educational standards and the changing discourse on education: The reception and consequences of the PISA study in Germany'. Oxford Review of Education, 32 (5), 619-34.

Fuller, S. (2018) Post-Truth: Knowledge as a power game. London: Anthem Press.

Giddens, A. (1990) The Consequences of Modernity. Cambridge: Polity Press.

Giddens, A. (1991) Modernity and Self-Identity: Self and society in the late modern age. Cambridge: Polity Press.

Gray, J. (1995) Enlightenment's Wake: Politics and culture at the close of the modern age. London: Routledge. 
Gray, J. (1996) Isaiah Berlin: An interpretation of his thought. Princeton: Princeton University Press. Gray, J. (2002) Two Faces of Liberalism. Cambridge: Polity Press.

Green, A. (2013) Education and State Formation: Europe, East Asia and the USA. 2nd ed. Basingstoke: Palgrave Macmillan.

Harvey, D. (2007) 'Neoliberalism as creative destruction'. Annals of the American Academy of Political and Social Science, 610, 22-44.

Hermann, S. (2007) Magt og oplysning: Folkeskolen 1950-2006. Copenhagen: Unge Pædagoger. Hirsch, E.D. (1987) Cultural Literacy: What every American needs to know. Boston: Houghton Mifflin. House of Commons Children, Schools and Families Committee (2008) Testing and Assessment: Third report of session 2007-08, Volume 1. London: The Stationery Office. Online. https://tinyurl.com/qngkja4 (accessed 25 November 2019).

Kelly, A. (1978) 'Introduction'. In Berlin, I. Russian Thinkers. London: Penguin, xxiii-xxxv.

Kelly, P. (2018) 'Standardized assessment and the shaping of neoliberal student subjectivities'. In Hamre, B., Morin, A. and Ydesen, C. (eds) Testing and Inclusive Schooling: International challenges and opportunities. London: Routledge, 64-78.

Kelly, P., Dorf, H., Pratt, N. and Hohmann, U. (2014) 'Comparing teacher roles in Denmark and England'. Compare: A Journal of Comparative and International Education, 44 (4), 566-86.

Kelly, P., Egedal Andreasen, K., Kousholt, K., McNess, E. and Ydesen, C. (2018) 'Education governance and standardised tests in Denmark and England'. Journal of Education Policy, 33 (6), 739-58.

Kelly, P., Hohmann, U., Pratt, N. and Dorf, H. (2013) 'Teachers as mediators: An exploration of situated English teaching'. British Educational Research Journal, 39 (4), 609-34.

Kelly, P. and Kotthoff, H.-G. (2016) 'Comparing episodes of mathematics teaching for higher achievers in England and Germany'. Research in Comparative and International Education, 11 (4), 394-405.

Kelly, P. and Kotthoff, H.-G. (2017) 'PISA, national and regional education policies and their effect on mathematics teaching in England and Germany'. Research in Comparative and International Education, 12 (3), 318-32.

Kelly, P., Pratt, N., Dorf, H. and Hohmann, U. (2013) 'Comparing pedagogy in mathematics in Denmark and England'. European Educational Research Journal, 12 (4), 553-67.

Lingard, B. (2011) 'Policy as numbers: Ac/counting for educational research'. Australian Educational Researcher, 38 (4), 355-82.

Lingard, B., Martino, W. and Rezai-Rashti, G. (2013) 'Testing regimes, accountabilities and education policy: Commensurate global and national developments'. Journal of Education Policy, 28 (5), 539-56.

Marx, K. (1975) 'Economic and philosophic manuscripts'. In Marx, K. Early Writings. London: Penguin, 279-400.

Mundy, K., Green, A., Lingard, B. and Verger, A. (eds) (2016) The Handbook of Global Education Policy. Chichester: Wiley Blackwell.

Nordin, A. and Sundberg, D. (eds) (2014) Transnational Policy Flows in European Education: The making and governing of knowledge in the education policy field. Oxford: Symposium Books.

OECD (Organisation for Economic Co-operation and Development) (2001) Knowledge and Skills for Life: First results from PISA 2000. Paris: Organisation for Economic Co-operation and Development.

Ozga, J. (2008) 'Governing knowledge: Research steering and research quality'. European Educational Research Journal, 7 (3), 261-72.

Sellar, S. and Lingard, B. (2014) 'The OECD and the expansion of PISA: New global modes of governance in education'. British Educational Research Journal, 40 (6), 917-36.

Sennett, R. (2009) The Craftsman. London: Penguin.

Stevenson, H. and Wood, P. (2013) 'Markets, managerialism and teachers' work: The invisible hand of high stakes testing in England'. International Education Journal: Comparative Perspectives, 12 (2), 42-61.

Waldow, F. (2009) 'What PISA did and did not do: Germany after the "PISA-shock"'. European Educational Research Journal, 8 (3), 476-83.

Whitty, G. and Furlong, J. (eds) (2017) Knowledge and the Study of Education: An international exploration. Oxford: Symposium Books.

Young, M.F.D. (2008) Bringing Knowledge Back In: From social constructivism to social realism in the sociology of education. London: Routledge. 